\title{
Anticyclonic atmospheric circulation as an analogue for the warm and dry mid-Holocene summer climate in central Scandinavia
}

\author{
K. Antonsson ${ }^{1}$, D. Chen ${ }^{2}$, and H. Seppä ${ }^{3}$ \\ ${ }^{1}$ Department of Earth Sciences, Uppsala University, Villavägen 16, 75236 Uppsala, Sweden \\ ${ }^{2}$ University of Gothenburg, Box 460, 40530, Göteborg, Sweden \\ ${ }^{3}$ Department of Geology, P.O. Box 64, 00014, University of Helsinki, Helsinki, Finland \\ Received: 26 March 2008 - Published in Clim. Past Discuss.: 16 May 2008 \\ Revised: 1 September 2008 - Accepted: 12 September 2008 - Published: 21 October 2008
}

\begin{abstract}
Climate reconstructions from central Scandinavia suggest that annual and summer temperatures were rising during the early Holocene and reached their maximum after 8000 cal yr BP. The period with highest temperatures was characterized by increasingly low lake-levels and dry climate, with driest and warmest conditions at about 7000 to $5000 \mathrm{cal}$ yr BP. We compare the reconstructed climate pattern with simulations of a climate model for the last 9000 years and show that the model, which is predominantly driven by solar insolation patterns, suggests less prominent midHolocene dry and warm period in Scandinavia than the reconstructions. As an additional explanation for the reconstructed climate, we argue that the trend from the moist early Holocene towards dry and warm mid-Holocene was caused by a changing atmospheric circulation pattern with a midHolocene dominance of summer-time anticyclonic circulation. An extreme case of the anticyclonic conditions is the persistent blocking high, an atmospheric pressure pattern that at present often causes long spells of particularly dry and warm summer weather, or "Indian summers". The argument is tested with daily instrumental temperature and precipitation records in central Sweden and an objective circulation classification based on surface air pressure over the period 1900-2002. We conclude that the differences between the precipitation and temperature climates under anticyclonic and non-anticyclonic conditions are significant. Further, warm and dry combination, as indicated by midHolocene reconstructions, is a typical pattern under anticyclonic conditions. These results indicate that the presented hypothesis for the mid-Holocene climate is likely valid.
\end{abstract}

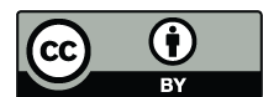

Correspondence to: $\mathrm{H}$. Seppä (heikki.seppa@helsinki.fi)

\section{Introduction}

It is well established that atmospheric circulation plays an important role in shaping the regional climate and influencing the marked intra-seasonal climatic variability over Scandinavia (e.g. Busuioc et al., 1999; Chen, 2000; Slonosky et al., 2000, 2001; Moberg and Jones, 2005; Achberger et al., 2007). Scandinavian summer climate is highly variable. It is often characterized by rainy and cloudy weather with daily maximum temperatures well below $20^{\circ} \mathrm{C}$, but can quickly switch into warm and dry weather, which sometimes persists over several weeks or even a few months (Johannessen, 1970). Daily maximum temperatures above $30^{\circ}$ and low precipitation are associated with clear skies and stable lower part of the atmosphere with minimal horizontal exchange. This kind of weather is often termed an "Indian summer" and it can persists several weeks with major impact on, for example, ground-water level, hydrological conditions, plant growth, and agricultural productivity (Johannessen, 1970; Lupo et al., 1997). The occurrence of these contrasting weather types is associated with changing dominance of atmospheric circulation patterns over northern Europe. The moist summers with relatively low temperatures are caused predominantly by strong zonal air flow and intensive occurrence of cyclones transporting moist air from the North Atlantic (Chen and Hellström, 1999). In contrast, the long warm and dry spells are related to the development of stationary anticyclonic conditions over the north-European landmass (Johannessen, 1970). The extreme form of anticyclonic conditions is the atmospheric blocking, defined as a long-lived and recurrent high-pressure system within the latitude belt of baroclinic westerlies (Rimbu et al., 2007). Blockings are an inherent and frequent feature in the European climate system, and their occurrence and prolonged duration has a particularly strong influence on climate in northern and north-western Europe (Rimbu et al., 2007; Carril et al., 2008). 


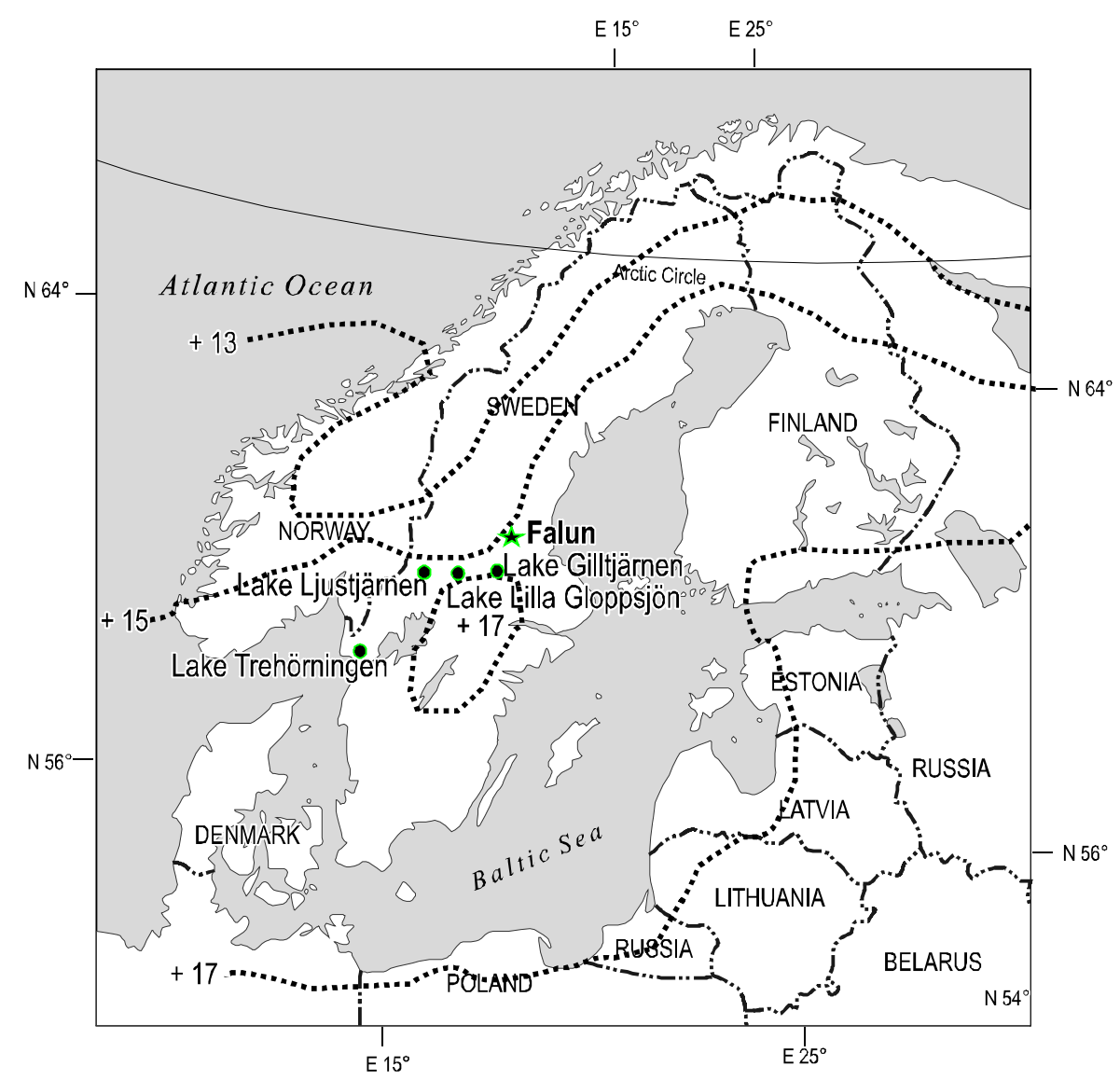

Fig. 1. The study area and the key study sites in central Sweden. The climatological analysis was carried out from the 1900-2002 climate data from Falun. The main July mean isotherms are marked on the figure.

Qualitative and quantitative palaeoclimate reconstructions have shown that on longer time-scales the climate in central Scandinavia has been characterized by periods with distinct and coeval changes in temperature and humidity. The reconstructions of summer and annual mean temperatures show the gradual rise of temperature during the early to mid-Holocene, with temperature during the Holocene thermal maximum at about $8000-4000$ cal yr BP about $1.5-2.5^{\circ} \mathrm{C}$ higher than the modern (1961-1990) values over large areas in central Scandinavia and the Baltic region (Seppä and Poska, 2004; Nesje et al., 2005; Seppä et al., 2005; Velle et al., 2005; Antonsson et al., 2006; Antonsson and Seppä, 2007), and the records which reflect effective precipitation have shown that the high summer temperatures were associated with low lake-levels and generally dry climatic conditions (Digerfeldt 1988; Almquist-Jacobson, 1995; Yu and Harrison, 1995; Vassiljev and Harrison, 1998; Hammarlund et al., 2003), possibly due to weaker zonal flow and higher summer evapotranspiration (Hammarlund et al., 2003; Seppä et al., 2005). Hence, in general the mid-Holocene summer climate shared the same principal features as the modern Indian summers in Scandinavia.
Unravelling the climatological processes that can explain the characteristics of the Holocene climate in northern Europe is a major palaeoclimatological challenge. One way to solve the problem is to amalgamate palaeoclimate records that reflect different climate parameters and provide thus a more holistic view on past climate patterns and subsystems (Seppä et al., 2005; Bakke et al., 2008). Here we focus on examining the patterns of the mid-Holocene warmth and dryness in central Sweden, based partly on new quantitative temperature reconstructions and partly on previously published records. In order to assess the climatological processes behind the reconstructed patterns, we compare the summarized palaeoclimatological picture with the trends of the solar insolation, the main external forcing factor, and the modelled climate. We aim to show that the climate simulations driven predominantly by solar insolation fail to explain the reconstructed mid-Holocene climate patterns. Instead, an analogue to the modern Indian summers may provide a clue to the problem: a potential solution can be obtained by interpreting the past climates in relation to the same atmospheric circulation patterns that cause the modern summers with particularly warm and dry weather. Thus, the working 
hypothesis is that the relatively warm and dry summers are associated with higher than normal frequencies of anticyclonic synoptic situations.

\section{Material and methods}

\subsection{Climate reconstructions and instrumental data}

The palaeoclimatological synthesis of the mid-Holocene climate is based on a number of palaeoclimatological proxy records from central Sweden (Fig. 1). The annual mean temperature $\left(T_{\mathrm{ann}}\right)$ was reconstructed from pollen-stratigraphical data, based on a methodology described in Seppä and Birks (2001) and Seppä et al. (2004). The calibration model used for providing the records is designed for Scandinavia and comprises of 173 modern pollen samples (Seppä et al., 2004; Antonsson et al., 2006). Pollen-climate transfer functions were developed with weighted-averaging partial least squares regression (ter Braak and Juggins, 1993). The predictive ability of the model was tested by leave-one-out cross validation (ter Braak and Juggins, 1993). The root-meansquare error of prediction (RMSEP) is $0.95^{\circ} \mathrm{C}$ and the $R^{2}$ between the predicted and observed modern annual mean temperature is 0.88 ; these statistics indicate a good performance of the model as compared to corresponding calibration models (Seppä and Bennett, 2003; Birks and Seppä, 2004). In addition to the previously published records from Lake Gilltjärnen and Lake Trehörningen (Fig. 1), an unpublished $T_{\mathrm{ann}}$ reconstruction is presented here from Lake Lilla Gloppsjön (Fig. 1), based on the unpublished pollen data by H. Almquist-Jacobson. A quantitative record of lake-level changes, indicative of effective precipitation, was obtained from Almquist-Jacobson (1995), based on the method developed by Digerfeldt (1988).

The modern climatological features of the study region were assessed on the basis of daily precipitation and temperature records in Falun $\left(60^{\circ} 37^{\prime} \mathrm{N}, 15^{\circ} 37^{\prime} \mathrm{E}, 160 \mathrm{~m}\right.$ a.s.l. $)$ in central Sweden (Fig. 1) during years 1900 to 2002 (Table 1). To study the impact of the synoptic conditions on the temperature and precipitation on the daily scale during summer (June-August), the seasonal cycle needs to be removed. The daily means of the 103 year records on each calendar day were taken as the seasonal cycle and subtracted from the daily records to come up with the daily anomalies of temperature and precipitation on each summer day. To make the interpretation easier, the daily precipitation anomalies were normalized with respect to the seasonal cycle by dividing it with the long- term means of each respective day.

\subsection{Atmospheric circulation classification}

To test the hypothesis according to which the summer temperature and precipitation in the study region are controlled by atmospheric circulation patterns, a synoptic classification is needed to classify the daily synoptic conditions into two
Table 1. Modern (1961-1990) climate characteristics at Falun meteorological station.

\begin{tabular}{lc}
\hline July mean temp & 16.0 \\
summer (JJA) mean temp & $15.1^{\circ} \mathrm{C}$ \\
January mean temp & -7.3 \\
winter (DJF) mean temp & $-6.5^{\circ} \mathrm{C}$ \\
annual mean temp & $4.2^{\circ} \mathrm{C}$ \\
summer ppt & $71 \mathrm{~mm}$ \\
annual ppt & $617 \mathrm{~mm}$ \\
\hline
\end{tabular}

groups, an anticyclonic and a non-anticyclonic group. The Lamb-Jenkinson object classification for atmospheric circulation has been successfully applied in Scandinavia (Chen and Li, 2004; Linderholm et al., 2007) and was used in this study. The classification is based on the manual scheme developed by Lamb (1950) for the British Isles. This scheme was automated by Jenkinson and Collison (1977) by defining a number of indices indicating the geostrophic wind and vorticity.

The classification of daily circulation types was based on daily mean sea-level pressure (SLP) data from the EMULATE project (Ansell et al., 2006). As in Chen (2000) for years 1850-2003, SLP data at 16 grid points were used. The Lamb-Jenkinson system has 27 possible circulation types, including 10 primary types (anticyclonic (A), cyclonic (C), westerly (W), southerly (S), easterly (E), northerly $(\mathrm{N})$, south-westerly (SW), south-easterly (SE), north-easterly (NE), north-westerly (NW), 16 hybrid types (anticyclone westerly (AW), cyclone westerly (CW) etc., and one unclassifiable group. In this study, A types and all the hybrid types associated with A were grouped together to represent the anticyclonic group, and the rest constitutes the nonanticyclonic group. Anticyclonic condition is characterized by a high pressure system centered either over the middle of the study area (A) or around it (AW, ASW, AS, ASE, AE, ANE, AN, ANW). For example, AW indicates that the study area is under the control of a high pressure system that is centered in south Sweden, causing a weakly westerly flow over the study area. When the centre of a high pressure system is located around the study area, the weather conditions are usually stable and the sky clear due to the weak gradient of the pressure and the descending flow (subsidence) in the central part of the high pressure. In summer, this type of weather is associated with warm and precipitation free (dry) conditions. At the same time, the non-anticyclonic group includes all the directional flows which show a consistent and relative strong pressure gradient and the cyclonic types. An important feature of the directional flows and $\mathrm{C}$ types is the unstable (fast moving systems) conditions and the ascending flow in the centre of a low pressure system. All these favour moisture transport, cloud formation and precipitation. Cloudy situation in summer also causes lower than normal day-time temperatures, which contribute to a lower daily mean temperature. 


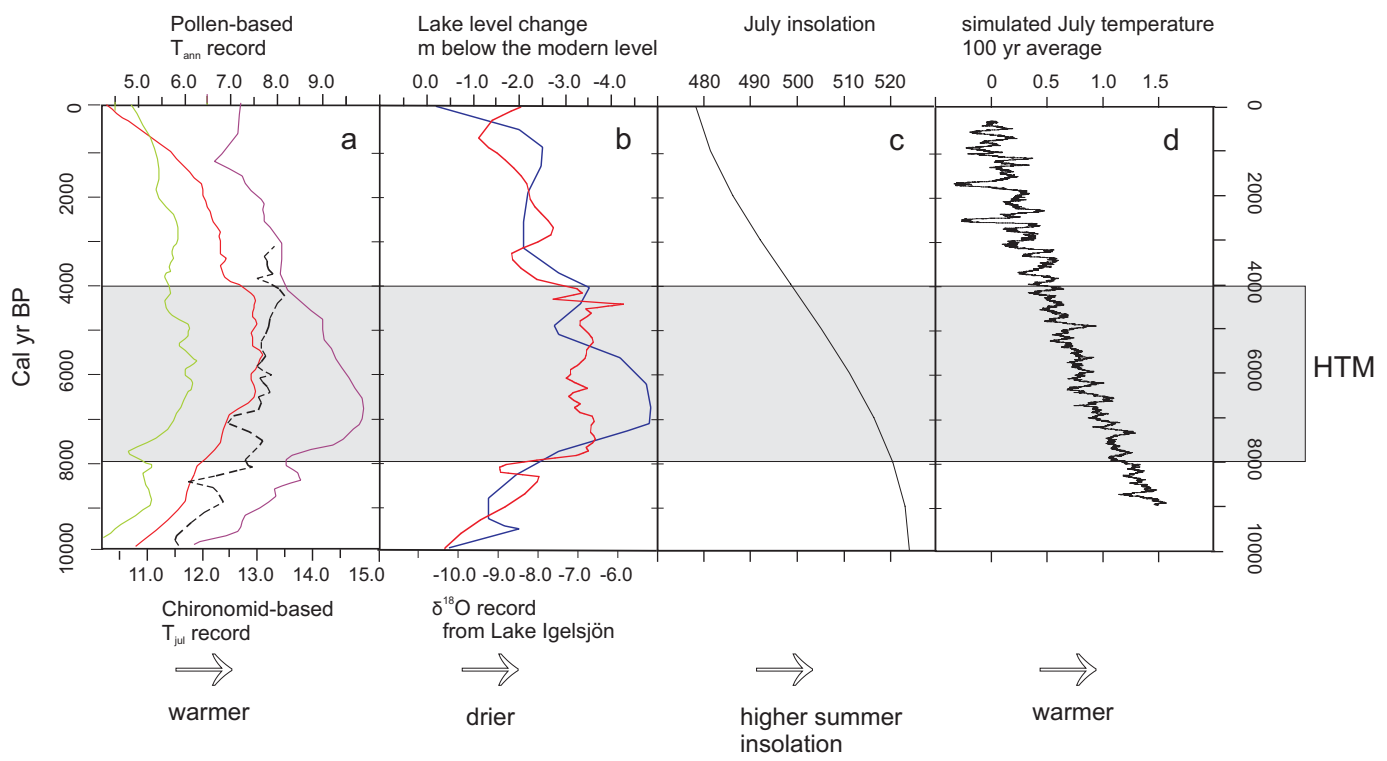

Fig. 2. Holocene temperature and humidity trends in the study area as reflected by a (a) pollen-based $T_{\text {ann }}$ record from Lake Gilltjärnen (light green curve) (Antonsson et al., 2006), a pollen-based $T_{\text {ann }}$ record from Lake Lilla Gloppsjön (red curve), a pollen-based $T_{\text {ann }}$ record from Lake Trehörningen (purple curve) (Antonsson and Seppä, 2007), and a chironomid-based $T_{\text {jul }}$ reconstruction for 10 000-3000 cal yr BP from Lake Gilltjärnen (broken line) (Antonsson et al., 2006). The records are shown with a LOESS smoother with a span of 0.10. (b) A lake-level reconstruction from Lake Ljustjärnen (blue curve). The scale is metres below the modern lake level (Almquist-Jacobson, 1995), and a $\delta^{18}$ O-record from Lake Igelsjön (red curve) (Hammarlund et al., 2003). The reconstructions are compared with (c) the July solar radiation trend for latitude $60^{\circ} \mathrm{N}$ North (Berger, 1978), and (d) the summer temperatures in Scandinavia $\left(62-74^{\circ} \mathrm{N}\right)$ as simulated by the coupled atmosphere-sea ice-ocean-vegetation model. The values are shown as a 100 -yr mean and as a deviation from the pre-industrial (1000-250 cal yr BP) mean of $13.1^{\circ} \mathrm{C}$ (Renssen et al., 2005).

\section{Results and discussion}

\subsection{Temperature records}

The pollen-based quantitative annual mean temperature records from Lakes Lilla Gloppsjön, Gilltjärnen and Trehörningen in central Sweden indicate coherent trends (Fig. 2a). They show that the early-Holocene temperature was low but steadily rising until about 8000 to 7000 cal yr BP, when it rose to the maximum Holocene level. This period of highest temperatures lasted until about $4000 \mathrm{cal}$ yr BP. As discussed by Antonsson et al. (2006), the pollen-based records in central Sweden do not provide a straightforward record of summer temperature because the distribution, population density, and pollen productivity of the plant species in the region do not depend solely on summer temperatures, but probably reflect more the predominant bioclimatic parameters such as the general temperatures during the growing season. However, these climatic parameters are highly correlated with the mean summer temperatures, and the records can therefore be viewed as predominantly reflecting the temperature trends during the summer-half of the year. This is supported by the chironomid-based July mean temperature $\left(T_{\text {jul }}\right)$ reconstruction from Lake Gilltjärnen, showing a midHolocene peak consistently with the pollen records (Fig. 2a).
Further information about the seasonal features of past climates can be obtained by analysing the distribution and abundance changes of indicator plant taxa. One of the most conspicuous features in the vegetation history of central Scandinavia is the rise of the pollen percentages of Tilia, most likely Tilia cordata, the most common Tilia species in Scandinavia, at about 8000 to $7000 \mathrm{cal} \mathrm{yr} \mathrm{BP}$ and the subsequent occurrence and sexual regeneration of the species up to about $200 \mathrm{~km}$ north of its modern northern continuous limit (Giesecke, 2005). The climatic requirements of Tilia cordata have been intensively studied. It is a species requiring high summer temperatures and somewhat dry conditions for establishment and growth (Hintikka, 1963; Prentice and Helmisaari, 1991; Skre, 1979; Pigott, 1981; Miller et al. 2008). In addition, it has a long lead root reaching deep in the soil, making it drought resistant, in contrast to Ulmus and Corylus, for example (Diekmann, 1996; Miller et al., 2008). The records show the rise of Tilia at 7500 to $6500 \mathrm{cal} \mathrm{yr} \mathrm{BP,}$ followed by maximum values at $6000 \mathrm{cal} \mathrm{yr} \mathrm{BP}$, and a gradual decline toward the present (Fig. 3). Given its climatic requirements, the relatively short-lived occurrence of Tilia therefore provides further evidence for the reconstructed dry and warm mid-Holocene climate. 


\subsection{Moisture balance variability}

The lake-level reconstructions are important for investigating past changes in hydrological balance, and, by inference, changes in past effective precipitation. The best regional Holocene moisture balance record from central Sweden is based on a lake-level reconstruction from Lake Ljustjärnen, a hydrologically closed kettle-hole lake on fluvioglacial terrain (Almquist-Jacobson, 1995). This record shows that the early-Holocene was characterized by a high lake-level, followed by a rapid and pronounced fall starting at about 8000 cal yr BP and culminating at about 7000 to $6000 \mathrm{cal}$ yr BP, with the Ljustjärnen water table falling about $4-5 \mathrm{~m}$ below the present level. This suggests a major mid-Holocene dry period consistently with the highest summer temperature. The dry period lasted until about $4000 \mathrm{cal} y \mathrm{BP}$ and was followed by rising or steady lake level (Fig. 2b). This pattern is in general consistent with the $\delta^{18} \mathrm{O}$-record obtained from lacustrine carbonate sediment from Lake Igelsjön in central Sweden (Hammarlund et al., 2003; Seppä et al., 2005). The marked increase of the $\delta^{18} \mathrm{O}$ values at 8000-4000 cal yr BP probably resulted from higher evaporation and lower water volume in the basin, leading to elevated $\delta^{18} \mathrm{O}$-values in relation to early and late-Holocene values (Fig. 2b). However, it is likely that the higher mid-Holocene $\delta^{18} \mathrm{O}$-values partly reflect weaker transport of moist, ${ }^{18} \mathrm{O}$-enriched Atlantic airmasses, thus suggesting a predominantly anticyclonic summertime circulation pattern, contrasting with the inferred enhanced early-Holocene transport of oceanic airmasses (Hammarlund et al., 2003; Seppä et al., 2005).

It is important that the reconstructed mid-Holocene dry period was not a local phenomenon restricted to central Sweden. Similar patterns have been observed in a number of lake-level reconstructions from northern Europe, reflecting the wide-spread nature of the dry period (Yu and Harrison, 1995). A precise investigation of the hydrological balance of Lake Bysjön in southern Sweden indicates a similar dry period at about 8000 to 4000 cal yr BP (Digerfeldt, 1988; Vassiljev and Harrison, 1998). In northern Fennoscandia, diatom and cladoceran stratigraphies from two lakes show that the climate at about 8000 to 4000 cal yr BP was characterized by a lowering of the lake level by 3-4 $\mathrm{m}$ and hence by markedly dry climate (Hyvärinen and Alhonen, 1994). Similar results have been obtained by quantitative lake-level reconstructions in Lapland (Korhola and Rautio, 2002; Korhola et al., 2005). Most lakes providing evidence for major changes of the lake level are small hydrologically closed lakes located in the fluvioglacial terrain, being thus particularly sensitive indicators of regional changes in the groundwater table.

\subsection{The quest for the mid-Holocene climatic drivers}

Climate simulations provide an important means to evaluate long-term climate trends under changing external forcing

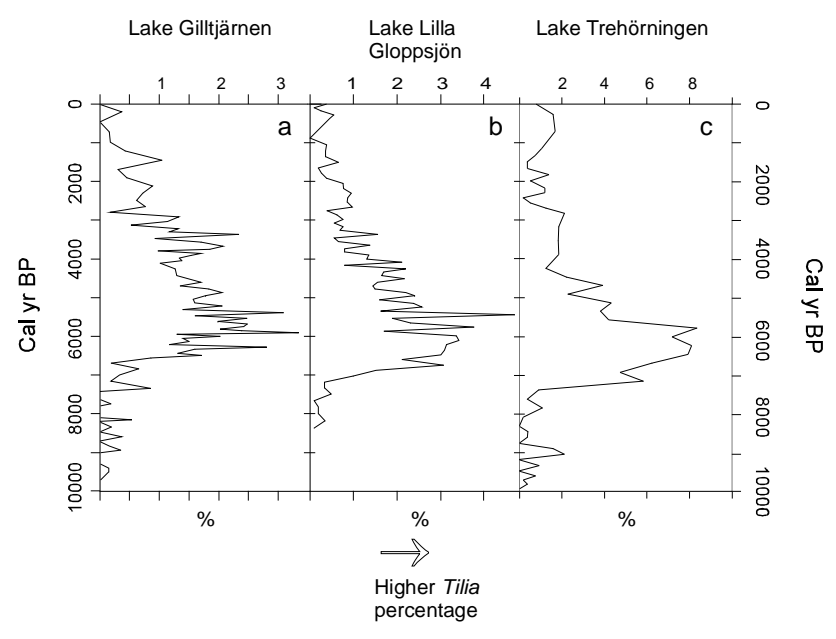

Fig. 3. The Holocene pollen percentage value of Tilia at (a) Lake Gilltjärnen (Antonsson et al., 2006), (b) Lake Lilla Gloppsjön (Almquist-Jacobson, unpublished) and (c) Lake Trehörningen (Antonsson and Seppä, 2007).

and have the potential to reveal the underlying climatological processes. A number of experiments have been carried out for northern Europe with models coupling the dynamics of atmosphere, ocean, sea ice, and vegetation (Masson et al., 1999; Braconnot et al., 2007). In many of these simulations the summer temperature is predominantly driven by the gradually decreasing summer solar insolation (Crucifix et al., 2002; Schmidt et al., 2004; Wohlfarth et al., 2004). A simulation carried out specifically for the last nine millennia in Scandinavia also shows this pattern (Renssen et al., 2005), suggesting that the highest summer temperatures were already reached at $9000-8000$ cal yr BP, followed by a gradual cooling towards the present, mainly as a result of declining annual and summer solar radiation trends (Fig. 2c and d). The simulated annual precipitation values demonstrate a relatively steady Holocene pattern, with no evidence for lower value during the mid-Holocene (Renssen et al., 2005).

Hence, the simulated summer temperature trend deviates from the observed pattern in central Scandinavia. The reconstructed summer temperature during the early-Holocene at 10000 to 8000 cal yr BP was low but steadily rising, in contrast to the highest Holocene values suggested by the models. After 7000 cal yr BP the simulation and reconstruction are more consistent, although the simulation shows a steadier fall of the temperature whereas the reconstructions show a longer period of higher mid-summer temperature and markedly dry climatic conditions. This climatic setting dominated until about 4000 cal yr BP and was then gradually replaced with cooler and moister summer climate (Fig. 2).

It is obvious that the simulations driven by the long-term solar insolation trend do not explain well all the features of the reconstructed palaeoclimates, which indicates that either the solar radiation was not the only forcing factor important 

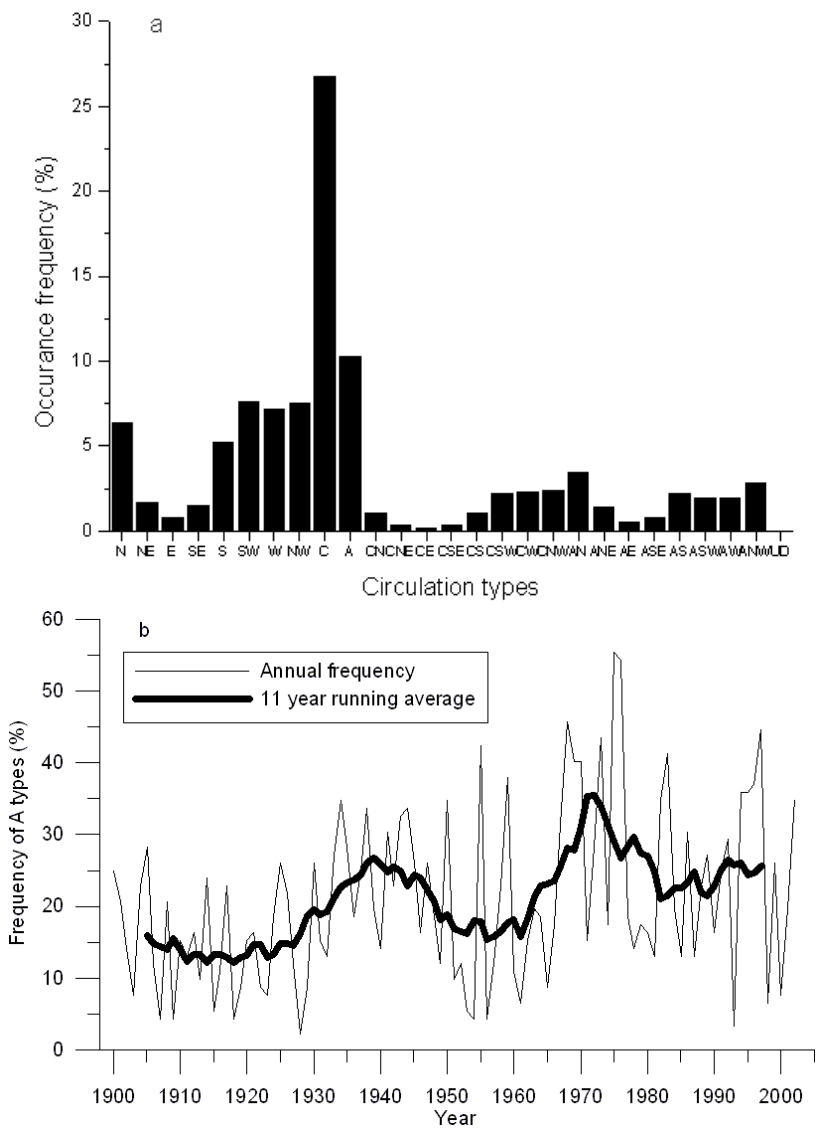

Fig. 4. (a) Annual occurrence of all the 26 circulation types over the summer months during 1850-2003 and (b) the variations of the frequency of anticyclonic group at 1900-2002.

to the climate, or such factors as atmospheric and oceanic circulation, ice sheet dynamics, and land-surface interactions with the atmosphere, having influences on the Scandinavia climate during the Holocene, were not well represented by the model. Therefore, the deviation between the model simulations and the climate reconstruction may be interpreted as deficiency of this particular model in simulating at least one of these processes.

A potential solution for the question of the mid-Holocene summer warmth and dryness can be obtained by assessing the observed modern synoptic summer weather types that most resemble the reconstructed mid-Holocene summer climate (Seppä and Birks, 2001). Such a comparison suggests an intriguing similarity between the modern Indian summers and the reconstructed mid-Holocene climate in Scandinavia, and an examination of atmospheric circulation dynamics leading to Indian summer weather can provide a circulation analogue for the mid-Holocene period. A typical, strong Indian summer weather was experienced in Scandinavia in 2002. After a rainy and relatively chilly late June, the North Atlantic region was dominated by a large and deep blocking anticyclone which persisted during the entire August 2002 from the mid-latitude North Atlantic up to the British Isles. The temperature rose over $25^{\circ} \mathrm{C}$ in mid July and stayed over this value for almost two months, until a rapid cooling on September 12. In Sweden several meteorological stations recorded temperatures $4-5^{\circ} \mathrm{C}$ above the mean value for $\mathrm{Au}$ gust and in Finland the highest August mean temperature was recorded at many meteorological stations. At the same time precipitation was extremely low in the eastern part of Sweden, with less than $50 \%$ of the seasonal long-term mean. August was the driest in Sweden since 1955. As a consequence of high temperature, high evapotranspiration and low precipitation, lake levels in central Finland fell $10-40 \mathrm{~cm}$ below seasonal mean, the ground-water table reaching critically low levels, $30-50 \mathrm{~cm}$ below the seasonal mean in some cases (SMHI, 2002; FMI, 2002).

The results of the analysis of the correlation between temperature, precipitation and the atmospheric circulation reflect the dominant role of atmospheric circulation pattern on the summer climate on decadal-scale. Figure 4a shows the distribution of the circulation types and the variations of the anticyclonic group over time in central Sweden. Over the summer period, the cyclonic and anticyclonic types dominate and all other types have a frequency below $10 \%$, which means that the non-cyclonic group is dominated by $\mathrm{C}$ types, while the anticyclonic group is mainly controlled by A types. Figure $4 \mathrm{~b}$ displays the annual frequencies of the anticyclonic group (A types) over 1900-2002 when the daily temperature and precipitations are available in Falun. Clearly there has been a considerable change of the frequency over the 103-year period, which would have a strong impact on the temperature and precipitation. A decadal change of the frequency is evident. It is interesting to note that the nonanticyclonic circulation groups were not always dominating, which shows that the atmospheric circulation is a highly variable factor and has the potential to control regional climate to a large extent.

The annual evolution of the summer temperature and precipitation anomalies for the two circulation groups are shown in Fig. 5. It clearly shows that the differences between the two groups are significant. While the mean temperature and precipitation anomalies over the whole period for the anticyclonic group are $+1.1^{\circ} \mathrm{C}$ (with a standard deviation of $0.9^{\circ} \mathrm{C}$ ) and $-69.3 \%$ (standard deviation $33.0 \%$ ), the corresponding means for the non-anticyclonic groups are $-0.1{ }^{\circ} \mathrm{C}$ (standard deviation $0.9^{\circ} \mathrm{C}$ ) and $+17.8 \%$ (standard deviation $33.4 \%$ ) respectively.

To quantify the impact the anticyclonic circulation on the summer climate, Fig. 6 shows the mean summer temperature and precipitation anomalies versus the frequency of the anticyclonic group. It is evident that the mean temperature (precipitation) is positively (negatively) correlated with the frequency of the anticyclonic group, which confirms the existence of the warm (cold)/dry (wet) combinations of the summer climate. While the correlations are all statistically 

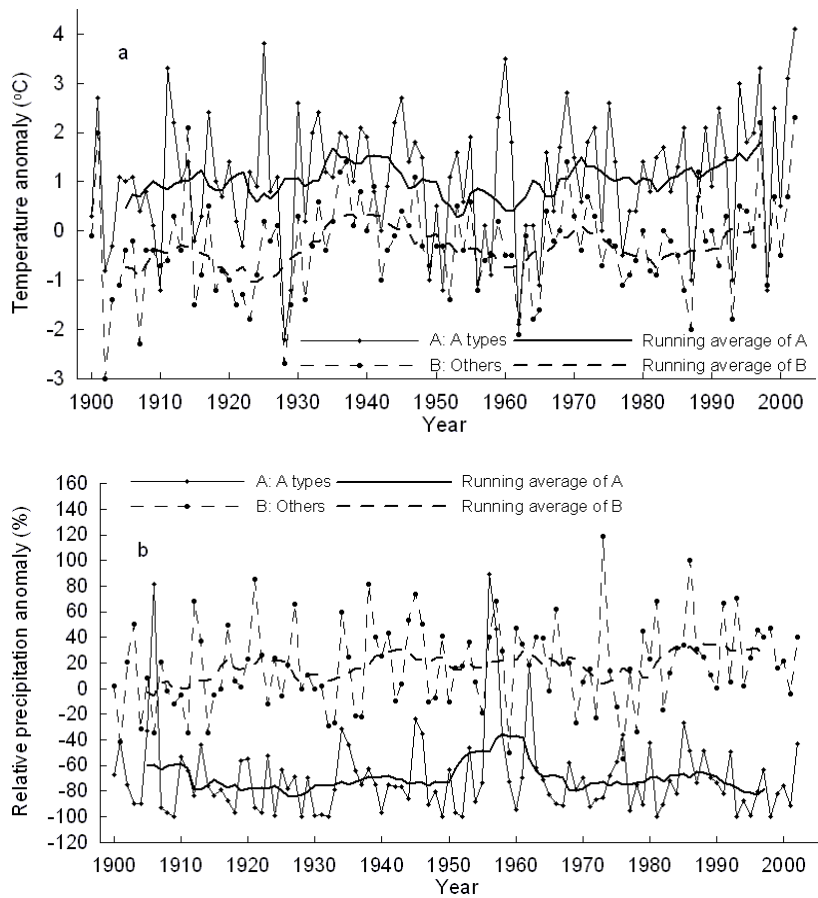

Fig. 5. Annual means of the summer temperature (a) and summer precipitation (b) anomalies for the anticyclonic types (A types) and non-anticyclonic group (others) the summer months during 2003. The running averages were made over an 11-year window.

significant at the $99.9 \%$ confidence level, the relationship is much stronger for temperature than for precipitation.

Thus, the results of the long-term time-series analysis show that the atmospheric circulation is variable on shorter (annual) to longer (decadal) time-scales in central Scandinavia. It is further clear that the predominant weather type is correlated with the dominant circulation type and that the anti-cyclonic circulation is the one which is associated with highest temperature. It is also correlated with low precipitation, but the correlation with precipitation and the circulation is less clear, possibly due to the local nature of the convective rains. However, warm and dry summers occur together and from the viewpoint of reconstructed climate features, with high summer temperatures in combinations with low lake levels from 7000 to $5000 \mathrm{cal}$ yr BP, this is an important piece in the quest for the mid-Holocene drivers. Obviously, the atmospheric circulation has a crucial role in modulating regional climates and is a strong candidate to explain to reconstructed warm and dry mid-Holocene summer climate in central Scandinavia.

\section{Conclusions}

Quantitative palaeoclimatology has developed rapidly during the recent years, with more complete understanding of
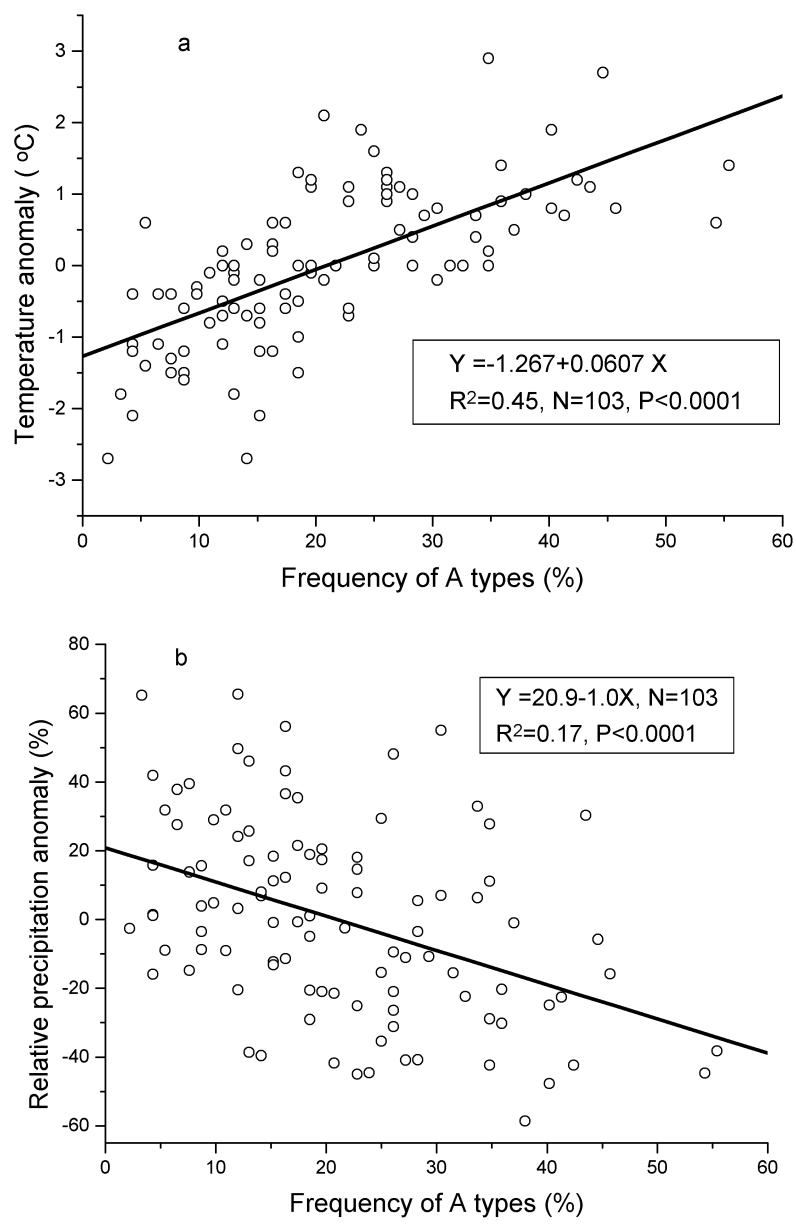

Fig. 6. Scatter plots showing the precision of the analysis on anticyclonic circulation and summer climate. Mean summer temperature is positively correlated with the annual frequency of the summertime anticyclonic group (a). Summer precipitation is negatively correlated with annual frequency of the summertime anticyclonic group (b).

the potentialities and pitfalls associated with the quantitative reconstruction procedures and the proxy techniques (Birks, 1998, 2003; Seppä and Bennett, 2003; Birks and Seppä, 2004; Brooks, 2006). The new techniques make it possible to reconstruct palaeoclimatic patterns in a more detailed and complete way, but the underlying climatic processes and causal relationships can not be understood directly on the basis of reconstructed patterns. One valuable approach for reconstructing the past processes is to analyse the relations between the modern synoptic climatological patterns and processes and use these modern settings as analogues for the past climatic periods (Mock and Brunelle-Daines, 1999; Edwards et al., 2001; Shrinker et al., 2006). This approach of modern analogues was applied in this study to investigate the mid-Holocene climate in central Sweden, a region where the modern climate is highly variable and dependent on the dominant atmospheric circulation mode. 
Quantitative reconstructions of summer and annual mean temperatures and lake levels from central Sweden, supported by stable isotopic data, and correlated with other comparable records from Scandinavia, indicate a predominantly warm and dry mid-Holocene climatic regime, deviating distinctly from humid early and late-Holocene climates and from the steadily decreasing summer solar radiation pattern. The large-scale geographical extent of these reconstructed climatic features suggests that they were controlled by changes in atmospheric circulation over Scandinavia. Modern climate analogues can provide means to determine how synopticscale controls may have given rise to observed past patterns of temperature and moisture conditions. As the modern analogue to the observed mid-Holocene climate pattern, we have established that anticyclonic synoptic conditions, with the blocking anticyclonic situation associated with the development of the "Indian summers" as an extreme case, favour a warm-dry combination and have had a significant impact on mean summer temperature and precipitation in central Sweden over 1900-2002. In addition, the variations of the frequency of this synoptic situation are large enough to produce significant changes in the climate. These results support the argument that the mid-Holocene summer may have been dominated by anticyclonic synoptic situations over Scandinavia

The underlying cause for the suggested Holocene variability in the occurrence and intensity of the anticyclonic circulation remains speculative. A possible solar influence on North Atlantic long-term variability, a potential factor for the centennial-scale variability (Jongma et al., 2007), is not a likely explanation for the mid-Holocene anticyclonic conditions, because there is no evidence for millennial-scale solar output anomaly during the mid-Holocene (Vonmoos et al., 2006). It is more probable that the millennial-scale dynamics over Scandinavia are related to the coupled atmosphereocean-ice interactions in the North Atlantic. Recent investigations have suggested that the multidecadal temperature signal in the North Atlantic, possibly associated with the changing intensity of the Atlantic meridional overturning circulation (AMOC), has had a significant influence on European multidecacal and centennial climate variability by modulating the atmospheric circulation patterns (Sutton and Hodson, 2005, 2007; Rimbu et al., 2007). As suggested by Sutton and Hodson (2007), these results are relevant to interpretation of proxy climate records for earlier times, when larger amplitude changes in the Atlantic Ocean have occurred, especially because they suggest that the past changes in the AMOC and the North Atlantic sea-surface temperatures may have significantly influenced the early- and mid-Holocene atmospheric circulation over the North-European landmass. A further amplification of the oceanic forcing may have been provided by the final disappearance of the Laurentide ice sheet at about 8000-7000 cal yr BP.
Acknowledgements. We thank Keith Bennett for valuable comments on the manuscript and for encouragement to go along with the idea, and Andrey Ganopolski and an anonymous referee for their comments. Financial support was provided by the Academy of Finland (HOT-project) and the University of Helsinki Environmental Research Centre (REBECCA project). Contribution from University of Gothenburg is taken as contribution No. 10 from TELLUS, the Centre for Earth System Science at University of Gothenburg. We also thank Charlotte Sweeney for correcting the English of the first version.

Edited by: J. Guiot

\section{References}

Achberger, C., Box, J. E., and Chen, D.: Nordic Region, in State of the Climate in 2006, in: Bulletin of the American Meteorological Society, edited by: Arguez, A., 88, S104-S106, 2007.

Almquist-Jacobson, H.: Lake-level fluctuations at Ljustjärnen, central Sweden and their implications for the Holocene climate of Scandinavia, Palaeogeogr. Palaeocl., 118, 269-290, 1995.

Ansell, J. T., Jones, P. D., Allan, R. J., et al.: Daily mean sea level pressure reconstructions for the European - North Atlantic region for the period 1850-2003, J. Climate, 19, 12, 2717-2742, doi:10.1175/JCLI3775.1, 2006.

Antonsson, K. and Seppä, H.: Holocene temperatures in Bohuslän, Southwestern Sweden: a quantitative reconstruction from fossil pollen data, Boreas, 36, 400-410, 2007.

Antonsson, K., Brooks, S. J., Seppä, H., Telford, R. J., and Birks, H. J. B.: Quantitative palaeotemperature records inferred from fossil chironomid and pollen assemblages from Lake Gilltjärnen, northern central Sweden, J. Quaternary Sci., 21, 831-841, 2006.

Bakke, J., Lie, Ø., Dahl, S. O., Nesje, A., and Bjune, A. E.: Strength and spatial patterns of the Holocene wintertime westerlies in the NE Atlantic region, Global Planet. Change, 60, 28-41, 2008.

Berger, A.: Long-term variations of caloric insolation resulting from the Earth's orbital elements, Quaternary Res., 9, 139-167, 1978.

Birks, H. J. B.: Numerical tools in quantitative palaeolimnology progress, potentialities, and problems, J. Paleolimnol., 20, 301332, 1998

Birks, H. J. B.: Quantitative palaeoenvironmental reconstructions from Holocene biological data, in: Global Change in the Holocene, edited by: Mackay, A., Battarbee, R. W., Birks, H. J. B., and Oldfield, F., Arnold, London, 107-123, 2003

Birks, H. J. B. and Seppä, H.: Pollen-based reconstructions of lateQuaternary climate in Europe - progress, problems, and pitfalls, Acta Palaeobotanica, 44, 317-334, 2004.

ter Braak, C. J. F. and Juggins, S.: Weighted averaging partial least squares regression (WA-PLS): an improved method for reconstructing environmental variables from species assemblages, Hydrobiologia, 269/270, 485-502, 1993.

Braconnot, P., Otto-Bliesner, B., Harrison, S., Joussaume, S., Peterchmitt, J.-Y., Abe-Ouchi, A., Crucifix, M., Driesschaert, E., Fichefet, Th., Hewitt, C. D., Kageyama, M., Kitoh, A., Loutre, M.-F., Marti, O., Merkel, U., Ramstein, G., Valdes, P., Weber, L., Yu, Y., and Zhao, Y.: Results of PMIP2 coupled simulations of the Mid-Holocene and Last Glacial Maximum -Part 2: feedbacks with emphasis on the location of the ITCZ and mid- and 
high latitudes heat budget, Clim. Past, 3, 279-296, 2007, http://www.clim-past.net/3/279/2007/.

Brooks, S. J.: Fossil midges (Diptera: Chironomidae) as palaeoclimatic indicators for the Eurasian region, Quaternary Sci. Rev., 25, 1894-1910, 2006

Busuioc, A., Chen, D., and Hellström, C.: Temporal and spatial variability of precipitation in Sweden and its link with the large scale atmospheric circulation, Tellus, 53A, 348-367, 2001.

Carril, A. F., Gualdi, S., Cherchi, A., and Navarra, A.: Heatwaves in Europe: areas of homogenous variability and link with the regional to large-scale atmospheric and SSTs anomalies, Clim. Dynam., 30, 77-98, 2008

Chen, D.: A monthly circulation climatology for Sweden and its application to a winter temperature case study, Int. J. Climatol., 20, 1067-1076, 2000.

Chen, D. and Hellström, C.: The influence of the North Atlantic Oscillation on the regional temperature variability in Sweden: spatial and temporal variations, Tellus, 51A, 505-516, 1999.

Chen, D. and Li, X.: Scale dependent relationship between maximum ice extent in the Baltic Sea and atmospheric circulation, Global Planet. Change, 41, 275-283, 2004.

Crucifix, M., Loutre, M.-F., Tulkens, P., Fichefet, T., and Berger, A.: Climate evolution during the Holocene: a study with an Earth system model of intermediate complexity, Clim. Dynam., 19, 43-60, 2002.

Diekmann, M.: Ecological behavior of deciduous hardwood trees in Boreo-nemoral Sweden in relation to light and soil conditions, Forest Ecol. Manag., 86, 1-14, 1996.

Digerfeldt, G.: Reconstruction and regional correlation of Holocene lake-level fluctuations in Lake Bysjön, South Sweden, Boreas, 17, 165-182, 1988.

Edwards, M. E., Mock, C. J., Finney, B. P., Barber, V. A., and Bartlein, P. J.: Potential analogues for palaeoclimatic variations in eastern interior Alaska during the past 14,000 yr: atmosphericcirculation controls of regional temperature and moisture responses, Quaternary Sci, Rev,, 20, 189-202, 2001.

FMI Finnish Meteorological Institute: Monthly hydrological report in August 2002, available online at: http://www.environment.fi, 2002.

Giesecke, T.: Holocene dynamics of the southern boreal forest in Sweden, The Holocene, 15, 858-872, 2005.

Hammarlund, D., Björck, S., Buchardt, B., Israelson, C., and Thomsen, C. T.: Rapid hydrological changes during the Holocene revealed by stable isotope records of lacustrine carbonates from Lake Igelsjön, southern Sweden, Quaternary Sci. Rev., 22, $353-$ 370, 2003

Hintikka, V.: Über das Grossklima einiger Pflanzenareale in zwei Klimakoordinatensystemen dargestellt, Annales Botanici Societatis Zoologicæ Botanicæ Fennicæ, Vanamo, 34, 1-63, 1963.

Hyvärinen, H. and Alhonen, P.: Holocene lake-level changes in the Fennoscandian tree-line region, western Finnish Lapland: diatom and cladoceran evidence, The Holocene, 4, 251-258, 1994.

Jenkinson, A. F. and Collison, F. P.: An initial climatology of gales over the North Sea, Synoptic Climatology Branch Memorandum, 62, Meteorological Office, Bracknell, 1977.

Johannessen, R. W.: The Climate of Scandinavia, in: Climates of Northern and Western Europe, World Survey of Climatology, edited by: Landsberg, H.E., Elsevier Publishing Company, Amsterdam, 5, 23-80, 1970.
Jongma, J. I., Prange, M., Renssen, H., and Schultz, M.: Amplification of Holocene multicentennial climate forcing by mode transitions in North Atlantic overturning circulation, Geophys. Res. Lett., 34, L15706, doi:10.1029/2007GL030642, 2007.

Korhola, A. and Rautio, M.: Cladocera and other brachiopod crustacean, in: Tracking Environmental Change Using Lake Sediments, 4, Zoological Indicators, edited by: Smol, J. P., Birks, H. J. B. and Last, W. M., Kluwer Academic Publishers, Dordrecht, 5-41, 2001.

Korhola, A., Tikkanen, M., and Weckström, J.: Quantification of Holocene lake-level changes in Finnish Lapland using a cladocera - lake depth transfer function, J. Paleolimn., 34, 175-190, 2005.

Lamb, H. H.: Types and spells of weather around the year in the British Isles, Q. J. Roy. Meteor. Soc., 76, 393-438, 1950.

Linderholm, H. W., Jansson, P., and Chen, D.: A high-resolution reconstruction of Storglaciären mass balance back to 1781 using tree-ring data and circulation indices, Quaternary Res., 67, 12 20, doi:10.1016/j.yqres.2006.08.005, 2007.

Lupo, A. R., Oglesby, R. J., and Mokhov, I. I.: Climatological features of blocking anticyclones: a study of Northern Hemisphere CCM1 model blocking events in present-day and double $\mathrm{CO}_{2}$ concentration atmospheres, Clim. Dynam., 13, 181-195, 1997.

Masson, V., Cheddadi, R., Braconnot, P., Joussaume, S., and Texier, D.: Mid-Holocene climate of Europe: what can we infer from PMIP model-data comparisons?, Clim. Dynam., 15, 165-182, 1999.

Miller, P. A., Giesecke, T., Hickler, T., Bradshaw, R. H. W., Smith, B., Seppä, H., Valdes, P. J., and Sykes, M. T.: Exploring climatic and biotic controls on Holocene vegetation change in Fennoscandia, J. Ecol., 96, 247-259, 2008.

Moberg, A. and Jones, P. D.: Trends in indices for extremes in daily temperature and precipitation in central and Europe, 1901-99, Int. J. Climatol., 25, 1149-1171, 2005.

Mock, G. and Brunelle-Daines, A. R.: A modern analogue of western United States summer palaeoclimate at 6000 years before present, The Holocene, 9, 541-545, 1999.

Nesje, A., Jansen, E., Birks, H. J. B., Bjune, A. E., Bakke, J., Andersson, C., Dahl, S. O., Klitgaard Kristensen, D., Lauritzen, S. E., Lie, Ø., Risebrobakken, B., and Svendsen, J.-I.: Holocene Climate Variability in the Northern North Atlantic Region: A Review of Terrestrial and Marine Evidence, in: The Nordic Seas, An Intergrated Perspective, edited by: Drange, H., Dokken, T., Furevik, T., Gerden, R., and Berger, R., American Geophysical Union, Washington, 289-322, 2005.

Pigott, C. D.: Nature of seed sterility and natural regeneration of Tilia cordata near its northern limit in Finland, Annales Botanici Fennici, 18, 255-263, 1981.

Prentice, I. C. and Helmisaari, H.: Silvics of north European trees: Compilation, comparisons and implication for forest succession modeling, Forest Ecol, Manag, 42, 79-93, 1991.

Renssen, H., Goosse, H., Fichefet, T., Brovkin, V., Driesschaert, E., and Wolk, F.: Simulating the Holocene climate evolution at northern high latitudes using a coupled atmosphere-sea iceocean-vegetation model, Clim. Dynam., 24, 23-43, 2005.

Rimbu, N., Lohmann, G., and Grosfeld, K.: Northern Hemisphere atmospheric blocking in ice core records from northern Greenland, Geophys. Res. Lett., 34, L09704, doi:10.1029/2006GL029175, 2007. 
Schmidt, G. A., Shindell, D. T., Miller, R. L, Mann, M. E., and Rind, D.: General circulation modelling of Holocene climate variability, Quaternary Sci. Rev., 23, 2167-2181, 2004.

Seppä, H. and Birks, H. J. B.: July mean temperature and annual precipitation trends during the Holocene in the Fennoscandian tree-line area: pollen-based climate reconstructions, The Holocene, 11, 527-539, 2001.

Seppä, H. and Bennett, K. D.: Quaternary pollen analysis: recent progress in palaeoecology and palaeoclimatology, Prog. Phys. Geog., 27, 580-611, 2003.

Seppä, H. and Poska, A.: Holocene annual mean temperature changes in Estonia and their relationship to solar insolation and atmospheric circulation patterns, Quaternary Res., 61, 22-31, 2004.

Seppä, H., Birks, H. J. B., Odland, A., Poska, A., and Veski, S.: Modern pollen surface sample set from northern Europe: developing and testing a tool for palaeoclimatological reconstructions, J. Biogeogr., 31, 251-267, 2004.

Seppä, H., Hammarlund, D., and Antonsson, K.: Low- and highfrequency changes in temperature and effective humidity during the Holocene in South central Sweden: Implications for atmospheric and oceanic forcings of climate, Clim. Dynam., 25, 285297, 2005.

Shrinker, J. J., Bartlein, P. J., and Shuman, B.: Synoptic and dynamic controls of North American mid-continental aridity, Quaternary Sci. Rev., 25, 1401-1417, 2006.

Skre, O.: The regional distribution of vascular plants in Scandinavia with requirements for high summer temperatures, Norw. J. Bot., 26, 295-318, 1979.

Slonosky, V. C., Jones, P. D., and Davies, T. D.: Variability of the surface atmospheric circulation over Europe, 1774-1995, Int. J. Climatol., 20, 1875-1897, 2000.
Slonosky, V. C., Jones, P. D., and Davies, T. D.: Atmospheric circulation and surface temperature in Europe from the 18th century to 1995, Int. J. Climatol., 21, 63-75, 2001.

SMHI.: Väder och Vatten, Direkt Offset AB, Norrköping, 8, 2002.

Sutton, R. T. and Hodson, D. L. R.: Atlantic Ocean forcing of North American and European summer climate, Science, 309, 115-118, 2005.

Sutton, R. T. and Hodson, D. L. R.: Climate Response to BasinScale Warming and Cooling of the North Atlantic Ocean, J. Climate, 20, 891-907, 2007.

Vassiljev, J. and Harrison, S. P.: Simulating the Holocene LakeLevel Record of Lake Bysjön, Southern Sweden, Quaternary Res., 49, 62-71, 1998.

Velle, G., Brooks, S. J., Birks, H. J. B., and Willassen, E.: Chironomids as a tool for inferring Holocene climate: an assessment based on six sites in south Scandinavia, Quaternary Sci. Rev., 24, 1429-1462, 2005.

Vonmoos, M., Beer, J., and Muscheler, R.: Large variations in Holocene solar activity: constraints from Be-10 in the Greenland Ice Core Project ice core, J. Geophys. Res.-Space, 111, A101105, doi:10.1029/2005JA011500, 2006.

Wohlfarth, J., Harrison, S. P., and Braconnot, P.: Synergistic feedbacks between ocean and vegetation on mid- and high-latitude climates during the mid-Holocene, Clim. Dynam., 22, 223-238, 2004.

Yu, G. and Harrison, S. P.: Holocene changes in atmospheric circulation patterns as shown by lake status in northern Europe, Boreas, 24, 260-268, 1995. 